\title{
Biomass, Carbon and Nitrogen Distribution in Living Woody Plant Parts of Robinia pseudoacacia L. Growing on Reclamation Sites in the Mining Region of Lower Lusatia (Northeast Germany)
}

\author{
Ansgar Quinkenstein, ${ }^{1}$ Dirk Pape, ${ }^{1}$ Dirk Freese, ${ }^{1}$ \\ Bernd Uwe Schneider, ${ }^{2}$ and Reinhard F. Hüttl1, 2 \\ ${ }^{1}$ Chair of Soil Protection and Recultivation, Brandenburg University of Technology, Konrad-Wachsmann-Allee 6, \\ 03046 Cottbus, Germany \\ ${ }^{2}$ GFZ German Research Centre for Geosciences, Helmholtz Centre Potsdam, Telegrafenberg, 14473 Potsdam, Germany
}

Correspondence should be addressed to Ansgar Quinkenstein, quinkenstein@tu-cottbus.de

Received 28 October 2011; Accepted 18 March 2012

Academic Editor: Levente Denes

Copyright (C) 2012 Ansgar Quinkenstein et al. This is an open access article distributed under the Creative Commons Attribution License, which permits unrestricted use, distribution, and reproduction in any medium, provided the original work is properly cited.

\begin{abstract}
In the lignite mining region of Lower Lusatia (NE-Germany), Robinia pseudoacacia L. is an increasingly popular tree for the biomass production with short rotation coppices (SRCs) on reclamation sites. In order to evaluate biomass production, $\mathrm{C}$ and $\mathrm{N}$ allocation patterns in R. pseudoacacia stands between shoot, stump, coarse, and fine roots samples were collected from seedlings and three adjacent plantations and plants that were one, two and twelve years old. Results indicated that the summarized average dry matter production (DM) of the woody plant parts increased with plant age up to $7.45 \mathrm{t} \mathrm{DM} \mathrm{ha-1} \mathrm{yr}^{-1}$ with a corresponding shoot increment of up to $4.77 \mathrm{t} \mathrm{DM} \mathrm{ha}^{-1} \mathrm{yr}^{-1}$ in the twelve-year-old stands. The shoot to root ratio changed from 0.2 for the oneyear-old trees to 2.0 in the twelve-year-old plantation, whereby an average amount of $3.4 \mathrm{t} \mathrm{Cha}^{-1} \mathrm{yr}^{-1}$ and $^{0.1} \mathrm{t} \mathrm{N} \mathrm{ha}^{-1} \mathrm{yr}^{-1}$ was annually bound in the living woody plant parts over the period of twelve years. Summing up, the results suggest a high potential for $\mathrm{C}$ and $\mathrm{N}$ storage of $\mathrm{R}$. pseudoacacia what is also beneficial for land reclamation due to positive implications on soil humus and general site fertility.
\end{abstract}

\section{Introduction}

Short rotation coppice (SRC) is an alternative land use system, usually established on agricultural sites, that aims for the fast production of woody biomass for energetical or material use. Within these systems, cuttings or saplings of fast growing trees such as poplar (Populus spp.), black locust (Robinia pseudoacacia L.), or willow (Salix spp.) are planted in high densities of typically up to 15,000 (and more) plants per hectare for willow and up to 12,000 plants per hectare for poplar or R. pseudoacacia. The planting pattern facilitates quick growth and easy harvesting at intervals of between two and six years. The cut trees are able to resprout following harvest, which allows such systems to be run for 20 to 30 years without replanting.
Dependent on the tree species, the growth conditions (climate, soil quality), and the management system (planting density, rotation interval, fertilization, pest control), the biomass productivity of SRC differs widely [1-4]. On agricultural sites of average fertility, dry matter (DM) yields between 8 and $14 \mathrm{tDM} \mathrm{ha}^{-1} \mathrm{yr}^{-1}$ for poplar and willow can be achieved under temperate conditions $[5,6]$, but, on marginal sites with nutrient-poor soils and a low water availability, the usual tree species poplar and willow show comparatively weak growth. A large area of marginal sites can be found in the open mining district of Lower Lusatia (State of Brandenburg, northeast Germany), which extends to a total area of about 31,000 ha in 2009 [7]. Growth experiments on reclamation sites within this region have resulted in aboveground growth rates of 2 to $6 \mathrm{tDM} \mathrm{ha}^{-1} \mathrm{yr}^{-1}$ for poplar 
and about $1 \mathrm{tDM} \mathrm{ha}^{-1} \mathrm{yr}^{-1}$ for willow $[8,9]$. On the same sites, high yields of woody biomass and average growth increments for $R$. pseudoacacia of about $5.8 \mathrm{tDM} \mathrm{ha}^{-1} \mathrm{yr}^{-1}$ dry matter were reported [9].

$R$. pseudoacacia is a pioneer species that grows remarkably fast in youth and produces wood with an oven-dry density of 0.7 to $0.8 \mathrm{~g} \mathrm{~cm}^{-3}[10,11]$, whereas hybrid poplars exhibit densities of 0.3 to $0.4 \mathrm{~g} \mathrm{~cm}^{-3}[12,13]$. The high wood density of $R$. pseudoacacia results in volume-related calorific values for $R$. pseudoacacia, which are significantly higher than the values for the other potential SRC species. Accordingly, Gruenewald et al. [9] reported calorific values of $4,818 \mathrm{MJ} \mathrm{m}^{-3}$ for $R$. pseudoacacia, 2,854 to $2,886 \mathrm{MJ} \mathrm{m}^{-3}$ for poplar, and $3,619 \mathrm{MJ} \mathrm{m}^{-3}$ for willow. This difference is economically relevant if the wood is used for bioenergy generation and storage or transport capacity is a limiting factor. In addition to the high biomass productivity on marginal sites, several studies also highlight the potential of $R$. pseudoacacia to enhance soil properties in terms of cation exchange capacity, biomass and organic carbon (C) accumulation [14, 15], nitrogen $(\mathrm{N})$ accumulation and nitrification [16-19], soil phosphate [20], as well as the potential to improve soil structure, soil stability, and to support revitalization of degraded land $[21,22]$. The ability to fix atmospheric $\mathrm{N}$ reduces the plants requirement for $\mathrm{N}$ fertilization compared to other energy species and, in combination with the general high biomass productivity, supports the restoration of a high and sustainable soil productivity on reclamation sites [23]. Furthermore, R. pseudoacacia is used in windbreaks and shelterbelts, as a nurse crop for honey production and as an ornamental tree $[24,25]$. Besides bioenergy production, the high quality wood is also utilized for the production of furniture and for many specialized purposes such as fence posts, mine timbers, poles, railroad ties, ship timber, and boxes $[24,26]$.

For the prospected life-time of SRC, these wood plantations do not only produce woody biomass for bioenergy but also accumulate large amounts of $\mathrm{C}$ within the aboveground and belowground woody plant parts. While the shoots are frequently cut and removed, the stump and the roots remain at the site after a harvest [27]. These plant parts form a midterm storage pool for $\mathrm{C}$ and also for $\mathrm{N}$, especially, if legume trees such as $R$. pseudoacacia are cultivated. Accordingly, SRC provides three different $C$ sequestration mechanisms: (1) production of woody biomass for bioenergy production (what helps reducing usage of fossil fuels and for this reason might be referred to as "indirect C sequestration"), (2) midterm C storage in living (woody) plant parts, and (3) longterm $\mathrm{C}$ storage due to buildup of soil organic matter (humus) as a consequence of biomass decomposition and incorporation of organic compounds within the soil organic $\mathrm{C}$ pool. However, little is known regarding the actual productive capacity, biomass accumulation in different plant parts, or effects on nutrient cycles of $R$. pseudoacacia on marginal reclamation sites. This paper examines the biomass production by $R$. pseudoacacia, grown in tree plantations in the Lower Lusatian mining district. The objective of this study was to highlight the variations of biomass distribution as well as $\mathrm{C}$ and $\mathrm{N}$ allocation in the shoot, stump, fine roots

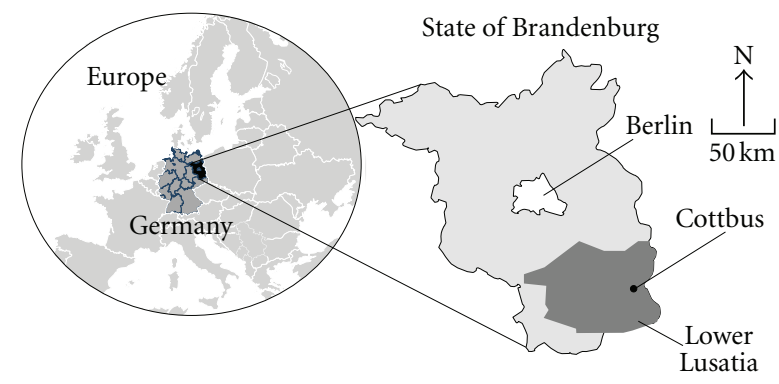

FIGURE 1: Location map of the lignite mining region of Lower Lusatia in NE Germany.

and coarse roots of one-, two-, and twelve-year-old $R$. pseudoacacia stands and to derive accumulation rates on an annually basis.

\section{Material and Methods}

2.1. Experimental Sites. Field experiments were performed in three plantations of $R$. pseudoacacia. The study sites are located in the Lower Lusatian region in the State of Brandenburg in northeast Germany (Figure 1) approximately $20 \mathrm{~km}$ south of the city of Cottbus $\left(51.6^{\circ} \mathrm{N}, 14.3^{\circ} \mathrm{E}\right)$ in the area of the lignite strip mining site "Welzow-Süd." The tree plantations were established in 1995 (WI), 2005 (WII), and 2006 (WIII), respectively, on reclamation sites within the former open-mining cast, now refilled, meliorated, and brought back into cultivation. For establishment of the SRC, one-year-old rooted seedlings were used. The survival rate in the first growth year was high for all plantations, and interspecies competition was minimal as the sites were nearly weed free. All sites are situated within a small area: WII and WIII adjoin each other, the WI site is located nearby (about $4 \mathrm{~km}$ distance).

Growth conditions in the area are characterized by an annual mean temperature of $9.3^{\circ} \mathrm{C}$ and an average annual precipitation sum of $556 \mathrm{~mm}$. During the main vegetation period (April to October), the average temperature is $14.2^{\circ} \mathrm{C}$ and the total precipitation sum is $375 \mathrm{~mm}$. The plantations are situated in a flat terrain at an average altitude between 120 and $130 \mathrm{~m}$ a.s.l. Substrates at the sites are derived from overburden material dumped during the course of lignite mining. Initial site mapping resulted in substrate types dominated by loamy sand at the WII and WIII sites (LMBV International $\mathrm{GmbH}$, pers. communication) and clayey sand at WI [8]. The nutrient status of the soils is generally low with typically less than $0.05 \% \mathrm{~N}$ in a soil depth of $0-30 \mathrm{~cm}$ [28]. Apart from the melioration, as described by Katzur and Haubold-Rosar [29], no additional fertilization was applied and no other cultivation activities were executed at any of the sites. The main characteristics of the experimental sites are given in Table 1.

2.2. Sampling. Samples were collected during the winters of $2006 / 2007$ and $2007 / 2008$. The plants were one (WIII), two $(W I I)$, and twelve $(W I)$ years old (counted as vegetation 
TABLe 1: Site descriptions of the three experimental sites with one-, two-, and twelve-year-old stands of Robinia pseudoacacia.

\begin{tabular}{lccc}
\hline & WIII & WII & WI \\
\hline Area (ha) & 8.6 & 13.2 & $<2.5$ \\
Site installation & 2006 & 2005 & 1995 \\
Origin of $R$. pseudoacacia & Müncheberg/Calvörde, Germany & Bihor, Romania & Unknown \\
Plant age at sampling (years) & 1 & 2 & 12 \\
Plant spacing & Double row: $(1.80 \mathrm{~m}+0.75 \mathrm{~m}) \times 0.85 \mathrm{~m}$ & Single row: $1.9 \mathrm{~m} \times 0.8 \mathrm{~m}$ \\
Unit soil area per plant $\left(\mathrm{m}^{2}\right)$ & 1.08 & 1.08 & 1.52 \\
Density (plants per ha) & 9200 & 9200 & 6500 \\
\hline
\end{tabular}

periods from the year of plantation establishment on). All trees were not cut before, and almost all of them had only one shoot. In each plantation, five sampling plots were established, representative of the overall plantation structure. At each plot, the shoot diameter of 30 randomly selected trees was measured and the average value calculated. For sampling, one tree with the average shoot diameter was selected. It was visually verified that the growth conditions of the sampling site were equal to the average conditions in the plantation and that the selected tree appeared vigorous and exhibited the average height as well as the average "general form" of the surrounding plants. The biomass of each selected tree was completely harvested. The aboveground shoots were sawn off and subdivided into stump $(0-10 \mathrm{~cm}$ from ground) and shoot $(>10 \mathrm{~cm})$.

Belowground root biomass was sampled in $15 \mathrm{~cm}$ depth intervals using an $8 \mathrm{~cm}$ diameter auger. At each selected tree, five auger holes were drilled, that is, at the base of the sampled tree, at $1 / 4$ and at $1 / 2$ the distance to the next tree within the same tree row, as well as $1 / 4$ and $1 / 2$ the distance to the next parallel tree row. R. pseudoacacia is known to develop a shallow but far reaching root system $[24,30]$. To determine rooting depths of the trees, three to four soil profiles were dug at the WIII and at the WII site. In accordance with the findings from these soil profiles, the overall sampling depth at the WIII site was set to $45 \mathrm{~cm}$ and at the WII site to $60 \mathrm{~cm}$. Sampling depth at the WI site was set to $90 \mathrm{~cm}$ due to practical considerations. Sampling with the root auger was limited to a root thickness of a maximum diameter of about $2.5 \mathrm{~cm}$. Roots with larger diameters could not be sampled with the utilized auger and at appropriate reliability. All roots exceeding $2.5 \mathrm{~cm}$ in diameter were followed until their diameter reached $2.5 \mathrm{~cm}$ and completely unearthed. Their biomass was added to the coarse root biomass and calculated with the remaining auger samples at a later date. Additionally, to get initial values for the biomass allocation patterns in new established plantations, black locust seedlings were sampled (sample "Initial"). This could be done easily without the use of an auger.

2.3. Sample Analysis. As eluded to previously, the sampled aboveground biomass was subdivided into stump (0 to $10 \mathrm{~cm}$ from the ground surface) and shoot (anything above $10 \mathrm{~cm}$ ) to comply with the common SRC management practices. In such plantations, the trees are frequently harvested and usually cut to an average height of $10 \mathrm{~cm}$ above the ground.
The stump then remains in the plantation, while the shoot biomass is removed.

Root core samples were washed with water and sieved with a mesh size of $1 \mathrm{~mm}$ to separate soil from the root biomass. The retained roots were divided into coarse (diameter $>2 \mathrm{~mm}$ ) and fine roots (diameter $\leq 2 \mathrm{~mm}$ ). Root nodules were treated separately. The corresponding measurement results were later added to the results of the fine root pool for data evaluation. Root fragments shorter than $1 \mathrm{~cm}$ as well as dead roots were discarded.

Biomass samples were dried at a maximum temperature of $65^{\circ} \mathrm{C}$ until weight was constant. Average aboveground biomass stock per compartment and hectare was determined by multiplying the average dry weight per plant with the average plant densities of the plantations (Table 1).

Carbon and nitrogen contents of the biomass samples were measured using a CNS analyzer (elmentar varioEL, Hanau/Germany). All plant parts (shoots, stump, coarse, and fine roots) were measured independently.

For calculation of the belowground biomass, a unit soil area per plant according to Bengough et al. [31] was defined (Table 1). The dimensions of this rectangular-shaped area were defined as half of the distance to the next tree in the tree row and to the next tree in the neighboring tree row. Based on the regular planting pattern within the plantations, it was assumed that the soil below each unit soil area contained a total root length equal to the mean root length per plant. Many of the roots within the minimum area may belong to neighboring plants, but, similarly, an equal number of roots from the plant may have extended outside the area. For each sampled tree, the root biomass in the unit soil area was calculated and then multiplied with the plant density to achieve the root biomass for the entire plantation.

Average annual shoot growth increments were calculated by dividing the shoot biomass by the corresponding plant age. The summarized average dry matter production of all woody plant parts was calculated by summarizing the shoot, stump, coarse root, and fine root biomass and dividing the result by the corresponding plant age. For the calculation of hectare related values for the seedling samples, a planting density of 9200 plants ha ${ }^{-1}$ such as in WIII and WII was assumed (see Table 1).

2.4. Statistical Analysis. The data sets were joined to form a pseudo-chronosequence from a tree age of one year up to an age of twelve years. GNU R [32] was used for the statistical 
TABLE 2: Average biomass per plant compartment and shoot : root ratio calculated as (shoot + stump)/(fine roots + coarse roots) for different plant ages of Robinia pseudoacacia (standard deviation is given as error).

\begin{tabular}{|c|c|c|c|c|}
\hline & \multicolumn{4}{|c|}{ Biomass (kg dry matter per plant) } \\
\hline & Initial & 1 years & 2 years & 12 years \\
\hline Coarse roots & $0.0010 \pm 0.0008$ & $0.1203 \pm 0.0624$ & $0.6663 \pm 0.6427$ & $4.0701 \pm 1.9718$ \\
\hline Fine roots & $0.0004 \pm 0.0003$ & $0.0622 \pm 0.0144$ & $0.1818 \pm 0.0394$ & $0.5546 \pm 0.0722$ \\
\hline Stump & $0.0010 \pm 0.0004$ & $0.0080 \pm 0.0013$ & $0.0601 \pm 0.0329$ & $0.3167 \pm 0.0739$ \\
\hline Shoot & $0.0041 \pm 0.0024$ & $0.0319 \pm 0.0081$ & $0.5556 \pm 0.2238$ & $8.8089 \pm 2.0447$ \\
\hline Shoot: root & 3.5 & 0.2 & 0.7 & 2.0 \\
\hline
\end{tabular}

TABLE 3: Average contents (all samples combined) and stocks of carbon and nitrogen in the woody biomass compartments (coarse roots, fine roots, stump and shoot) of seedlings ("Initial") and three differently aged stands of Robinia pseudoacacia (standard deviation is given as error).

\begin{tabular}{|c|c|c|c|c|c|}
\hline & \multirow{2}{*}{$\begin{array}{c}\text { Organic Carbon } \\
(\%)\end{array}$} & \multicolumn{4}{|c|}{ Organic Carbon $\left(\mathrm{kg} \cdot \mathrm{ha}^{-1}\right)$} \\
\hline & & Initial & 1 years & 2 years & 12 years \\
\hline Coarse roots & $43.4 \pm 1.4$ & $4.3 \pm 3.0$ & $477.9 \pm 260.7$ & $2650.0 \pm 2563.2$ & $11512.5 \pm 5560.7$ \\
\hline Fine roots & $41.9 \pm 1.0$ & $1.7 \pm 1.3$ & $251.4 \pm 41.9$ & $712.2 \pm 167.6$ & $1508.2 \pm 209.5$ \\
\hline Stump & $46.8 \pm 1.4$ & $4.2 \pm 1.9$ & $46.8 \pm 0.0$ & $281.0 \pm 140.5$ & $983.4 \pm 234.2$ \\
\hline \multirow[t]{3}{*}{ Shoot } & $46.4 \pm 1.0$ & $17.6 \pm 10.2$ & $139.2 \pm 46.4$ & $2365.8 \pm 974.1$ & $26579.9 \pm 6169.5$ \\
\hline & Nitrogen & \multicolumn{4}{|c|}{ Nitrogen $\left(\mathrm{kg} \cdot \mathrm{ha}^{-1}\right)$} \\
\hline & $(\%)$ & Initial & 1 years & 2 years & 12 years \\
\hline Coarse roots & $1.8 \pm 0.6$ & $0.2 \pm 0.1$ & $20.0 \pm 10.9$ & $110.8 \pm 107.2$ & $481.4 \pm 232.5$ \\
\hline Fine roots & $3.0 \pm 0.4$ & $0.1 \pm 0.1$ & $18.0 \pm 3.0$ & $51.0 \pm 12.0$ & $108.1 \pm 15.0$ \\
\hline Stump & $1.1 \pm 0.5$ & $0.1 \pm 0.0$ & $1.1 \pm 0.0$ & $6.6 \pm 3.3$ & $23.0 \pm 5.5$ \\
\hline Shoot & $1.2 \pm 0.5$ & $0.5 \pm 0.3$ & $3.7 \pm 1.2$ & $63.6 \pm 26.2$ & $714.7 \pm 165.9$ \\
\hline
\end{tabular}

exploration and plotting of the data sets. The data were tested for significant differences between the different plantations with the nonparametric Mann-Whitney U-test [33].

\section{Results}

Biomass accumulation in the first two years of growth was seen to be rapid in the $R$. pseudoacacia plantations. The results showed a distinct increase in the biomass of each plant compartment with plant age (Tables 2 and 3). Average stocks per hectare ranged for shoot biomass from $0.04 \mathrm{t} \mathrm{DM} \mathrm{ha}^{-1}$ for the seedlings and $0.29 \mathrm{t} \mathrm{DM} \mathrm{ha}^{-1}$ for oneyear-old plants to $57.26 \mathrm{tDM} \mathrm{ha}^{-1}$ for the twelve-year-old plants (Figure 2). While the biomass stocks for stump were 0.01 to $2.1 \mathrm{tDM} \mathrm{ha}^{-1}$, the stocks for coarse roots were 0.01 to $26.5 \mathrm{t} \mathrm{DM} \mathrm{ha}^{-1}$ and for fine roots 0.004 to $3.6 \mathrm{tDM} \mathrm{ha}^{-1}$, respectively (Figure 2 ). The corresponding total $\mathrm{C}$ stocks in the biomass were $27.8 \mathrm{~kg} \mathrm{Cha}^{-1}$ for the seedlings, $915.3 \mathrm{~kg} \mathrm{Cha}^{-1}$ for the one-year-old, $6,009.0 \mathrm{~kg} \mathrm{Cha}^{-1}$ for the two-year-old and $40,584.0 \mathrm{~kg} \mathrm{C} \mathrm{ha}^{-1}$ for the twelve-yearold plants. The measured average $\mathrm{C}$ contents in the biomass pools were $43.4 \%$ for coarse roots, $41.9 \%$ for fine roots, $46.8 \%$ for stump, and $46.4 \%$ for shoot (Table 3 ). Differences in absolute biomass for each compartment and stand age were found to be significant for shoot, stump, coarse, and fine roots $(P<0.05)$ with higher values in older stands. Only for the coarse root biomass between the two-and the twelveyear-old plants, a slightly lower significance level of $P=0.07$ was calculated.

The overall annual shoot growth increment was seen to be increasing in the first years starting at $0.29 \mathrm{tDM} \mathrm{ha}^{-1} \mathrm{yr}^{-1}$ for the one-year-old plants, continuing with $2.56 \mathrm{tDM} \mathrm{ha}^{-1} \mathrm{yr}^{-1}$ for the two-year-old and 4.77 t DM ha ${ }^{-1} \mathrm{yr}^{-1}$ for the twelve-year-old plants (Figure 3). The increase was significant comparing the one-, two- and twelve-year-old stand $(P<0.05$; Figure 3), indicating a general higher biomass productivity in older stands. Coarse root growth increments did not show significant differences between stand ages. The fine root growth increments decreased comparing the one- and two-year-old stands with the twelve years old stand $(P<0.05)$ with no significant difference between the one- and the two-year-old plantation. The annual stump growth increments were significantly lower in the one-year-old stand compared to the two-yearold stand as well as compared to the twelve-year-old stand $(P>0.05)$, but no significant difference was observed between two and twelve years.

Comparing the different aged plants, the relative allocation of the biomass compartments is seen to change (Figure 4 , Table 2). The ratio of shoot (aboveground biomass) to root (belowground biomass) for the seedlings is 3.5 (78\%:22\%) and changes to $0.2(18 \%: 82 \%)$ for the one-year-old plants, respectively; to $0.7(42 \%: 58 \%)$ for the two-year-old plants 


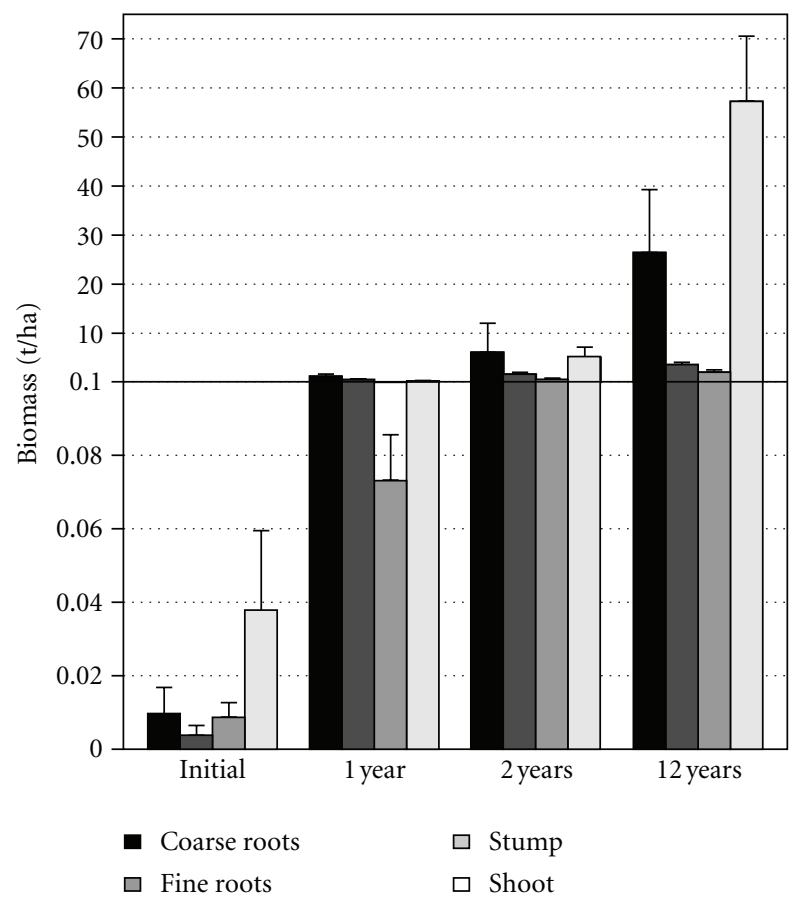

FIgUre 2: Absolute dry matter distribution of the woody biomass compartments shoot, stump, fine roots and coarse roots, for seedlings (Initial), a one-, two- and a twelve-year-old stand of Robinia pseudoacacia (standard deviation is plotted as error bar).

and reaches a value of $2.0(66 \%: 34 \%)$ for the twelve-year-old plants (Table 2). In Figure 5, the logarithmized belowground biomass (coarse roots + fine roots) versus aboveground biomass (stump + shoot) is presented. The plot reveals a strong increase of root biomass during the first vegetation period (initial value compared to the one-year-old plants) with a slope $>1$. This allocation pattern changes between the one-year and the two-year-old plants, and then more biomass is allocated to the aboveground biomass than to the belowground biomass ( slope $<1$ ).

$\mathrm{C} / \mathrm{N}$ ratios for the one-, two- and twelve-year-old stands were $29.9,31.6$, and 81.0 for the shoots, $30.7,48.2$, and 84.2 for the stump, 13.2, 13.6, and 15.7 for the fine roots and $19.0,25.0$, and 37.9 for the coarse roots. Total $\mathrm{N}$ stocks in the woody biomass amounted to $0.9 \mathrm{~kg} \mathrm{~N} \mathrm{ha}^{-1}$ for the seedlings (assuming 9200 plants ha ${ }^{-1}$ ), $42.8 \mathrm{~kg} \mathrm{Nha}^{-1}$ for one-year, $232.0 \mathrm{~kg} \mathrm{Nha}^{-1}$ for two-year, and $1327.2 \mathrm{~kg} \mathrm{Nha}^{-1}$ for the twelve-year-old plants. For the calculation the measured average $\mathrm{N}$ contents of $1.8 \%$ in the coarse roots, $3.0 \%$ in the fine roots (including root nodules), $1.1 \%$ in the stump, and $1.2 \%$ in the shoot were used (Table 3 ).

\section{Discussion}

4.1. Biomass Productivity of R. pseudoacacia. The shoot compartment represents yield biomass and therefore the direct economical value of an energy plantation. The obtained results for the biomass productivity of $R$. pseudoacacia on the study sites resemble those reported in literature. Gruenewald et al. [9] investigated biomass accumulation of

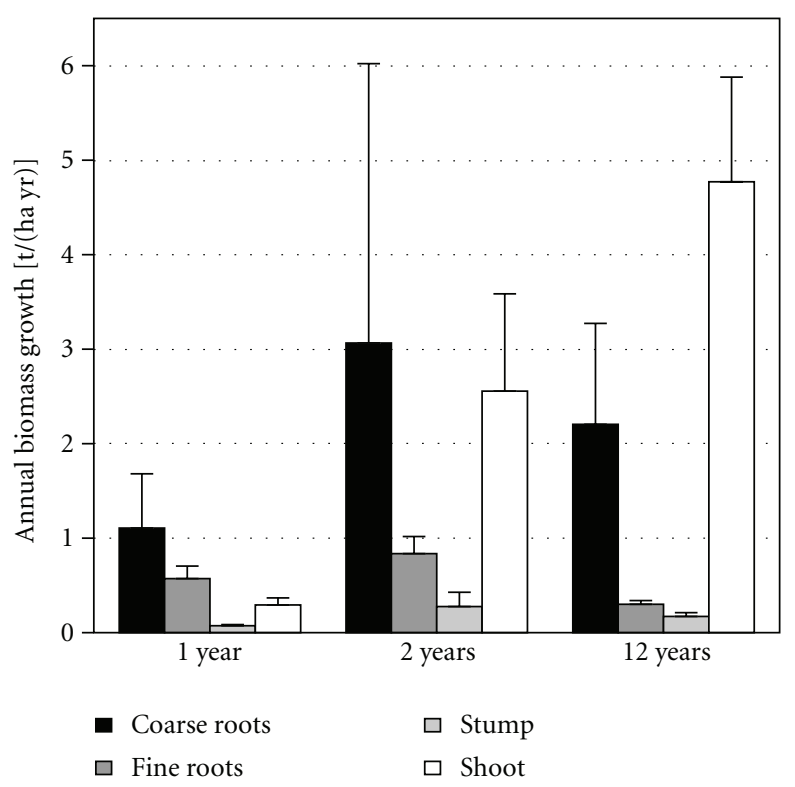

FIgURE 3: Plot of the average annual growth of the woody biomass compartments shoot, stump, fine roots, and coarse roots of a one-, two-, and a twelve-year-old stand of black locust (Robinia pseudoacacia).

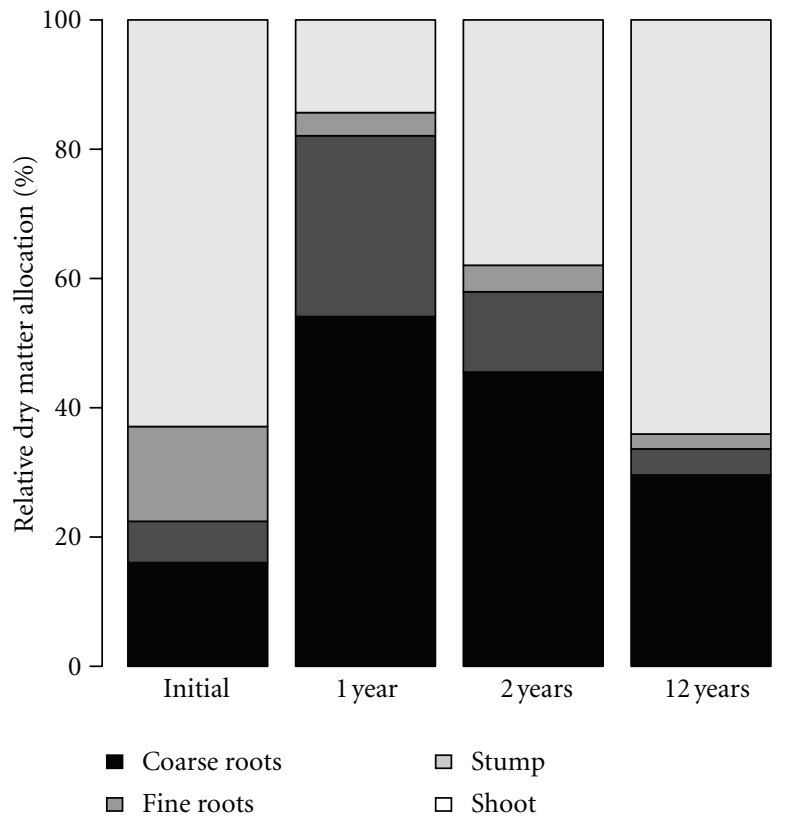

FIGURE 4: Relative dry matter distribution of the woody biomass compartments shoot, stump, fine roots, and coarse roots of seedlings (Initial), a one-, two-, and a 12-year-old stand of black locust (Robinia pseudoacacia).

R. pseudoacacia in an alley cropping system on a reclamation site in the Lusatian lignite-mining district (Brandenburg, Germany) and reported values of $29.8 \mathrm{tDM} \mathrm{ha}^{-1}$ after six years and a peak biomass productivity of $5.8 \mathrm{tDM} \mathrm{ha}^{-1} \mathrm{yr}^{-1}$. Furthermore, they reported average biomass accumulations ranging from 3.2 to $4.6 \mathrm{tDM} \mathrm{ha}^{-1} \mathrm{yr}^{-1}$ after two years in an 


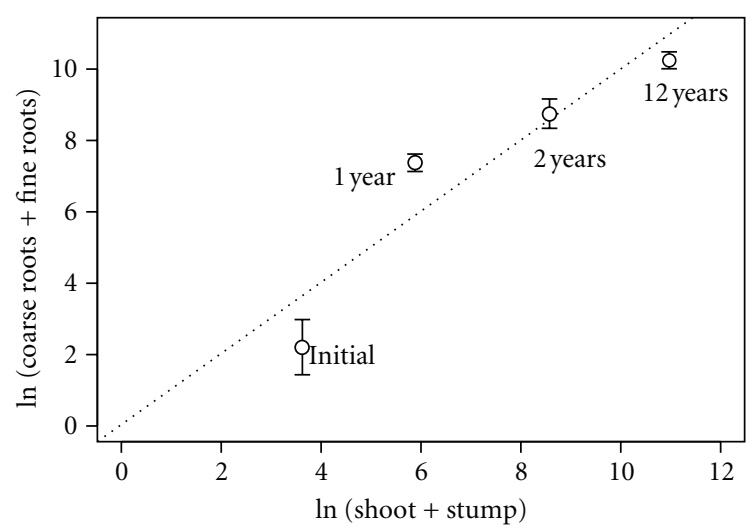

Figure 5: Plot of the aboveground (stump + shoot) versus the belowground biomass (coarse + fine roots) of seedlings (Initial), a one-, two-, and a 12-year-old stand of black locust (Robinia pseudoacacia).

alley cropping system in the Helmstedt lignite-mining district (Lower Saxony, Germany). Even higher annual growth increments of up to $9.5 \mathrm{tDM} \mathrm{ha}^{-1} \mathrm{yr}^{-1}$ were reported by Grünewald et al. [34] for a fourteen-year-old $R$. pseudoacacia plantation on reclamation sites in the Lusatian mining area of "Welzow-Süd" (Brandenburg, Germany). Also, in "Welzow-Süd," Böhm et al. [35] investigated a R. pseudoacacia SRC and reported an average biomass productivity of about $3 \mathrm{tDM} \mathrm{ha} \mathrm{D}^{-1} \mathrm{yr}^{-1}$ for the first three years of growth. Peters et al. [36] measured average annual growth rates of $5.5 \mathrm{tDM} \mathrm{ha}^{-1} \mathrm{yr}^{-1}$ for $R$. pseudoacacia on study sites in Brandenburg with plant densities of between 4100 and 5700 trees $\mathrm{ha}^{-1}$ following six years. Growth data on $R$. pseudoacacia reported from other temperate regions present similar findings. Rédei et al. [26] investigated the growth of different $R$. pseudoacacia clones growing on marginal sites in Hungary and measured mean annual increments of 2.9 to $9.7 \mathrm{tDM} \mathrm{ha}^{-1} \mathrm{yr}^{-1}$ at ages between 3 and 7 years using a stocking density of 6667 trees ha ${ }^{-1}$. Bongarten et al. [23] reported 3 to $8 \mathrm{tDM} \mathrm{ha}^{-1} \mathrm{yr}^{-1}$ after three years of growth in an intensive short-rotation system in the Piedmont region of Georgia (USA). Dickmann et al. [37] measured $R$. pseudoacacia growth in the same region and found average values after four years of growth of $4.2 \mathrm{tDM} \mathrm{ha}^{-1} \mathrm{yr}^{-1}$ and in Eastern Kansas (USA) Geyer [1] found comparatively high average growth rates of $14.2 \mathrm{tDM} \mathrm{ha}^{-1} \mathrm{yr}^{-1}$ with planting densities of around 1400 to 7000 trees ha $^{-1}$ after five years.

Remarkably, the measured growth increments of R. pseudoacacia were at least equal to those of poplar or willow under comparable growth conditions. Accordingly, Gruenewald et al. [9] measured average growth increments for two poplar clones (Hybrid 275 and Androscoggin) of 1.1 to $2.0 \mathrm{tDM} \mathrm{ha}^{-1} \mathrm{yr}^{-1}$ and for willow of $1.0 \mathrm{tDM} \mathrm{ha}^{-1} \mathrm{yr}^{-1}$ after a rotation of six years at the Lusatian alley cropping system. For the Helmstedt study site biomass accumulations between $2.2 \mathrm{tDM} \mathrm{ha}^{-1} \mathrm{yr}^{-1}$ and $3.9 \mathrm{tDM} \mathrm{ha}^{-1} \mathrm{yr}^{-1}$ were reported for Androscoggin and Hybrid 275, respectively. Bungart and Hüttl [8] investigated the growth of different hybrid poplar clones in a short-rotation plantation on another neighboring reclamation site in the mining-area of "Welzow-Süd" and found aboveground biomass accumulations ranging from 24 to $49 \mathrm{t} \mathrm{DM} \mathrm{ha}{ }^{-1}$ at age 8 , corresponding to a growth rate of 2.7 to $5.4 \mathrm{tDM} \mathrm{ha}^{-1} \mathrm{yr}^{-1}$.

The study results suggest that at least in the Lusatian region $R$. pseudoacacia is very productive compared to willow and poplar, and therefore a promising tree for biomass production. This is especially true for the harsh growth conditions on marginal reclamation sites.

4.2. Biomass Allocation. The proportion of biomass allocated belowground increased considerably within the early growth years (Figure 4). The data suggest that in the state of planting (label "Initial") the aboveground biomass (shoot and stump) dominates clearly with a share of $78 \%$ of the total biomass. This allocation pattern reflects the growth conditions in the seed bed and might be influenced by a general loss of root biomass caused by replanting the seedlings from the seed bed into the plantation. Therefore, the results of the seedlings may not reflect an undisturbed growth of $R$. pseudoacacia. In the subsequent early growing seasons, the plants seem to invest a lot in the expansion of their root systems; the aboveground plant parts become more and more dominant and at the age of twelve, the distribution of the biomass has changed. Aboveground growth has overhauled root growth and as a result the aboveground biomass represents $66 \%$ of total biomass which corresponds with a shoot: root ratio of 2. Figure 5 indicates that equilibrium appears to have been reached between ages 2 and 12 (slight gradient between two and twelve years) meaning allometry has become constant. Such a distribution of biomass allocated aboveground to that belowground is frequently found in mature forests, whereas the reported ratios vary considerably $[38,39]$.

The observed change in the shoot: root ratio reflects a typical change during the plant life cycle, because usually, the relative mass of belowground organs increases from the juvenile to the generative stage and decreases during the senile stage [40]. Comparable shoot: root ratios were reported by Boring and Swank [41] who found for a 4, a 17, and a 38 years old $R$. pseudoacacia stand root fractions of 33\%, $18 \%$, and $18 \%$ compared to total biomass, corresponding to shoot: root ratios of $2.0,4.6$ and 4.6 , respectively. The authors found higher values for older stands, but took root samples from $0-30 \mathrm{~cm}$ only. In contrast, in the presented study measurements were performed down to a soil depths of $90 \mathrm{~cm}$ in the oldest stand. Furthermore, Boring and Swank [41] used allometric functions to estimate large lateral root biomass. These differences in approach might have contributed to lower reported shares of total root biomass by Boring and Swank [41], especially for the older stands.

However, studies on the $\mathrm{C}$ allocation patterns of $R$. pseudoacacia in biomass plantations are very limited. For poplar and willow more comprehensive studies have been conducted. Accordingly, Coleman et al. [42] investigated C allocation in young poplar plantations (Populus deltoides Bartr.) in the USA and found a shoot: root ratio of 2.3 for an unfertilized one year old plantation. Liberloo et al. [43] investigated different poplar clones at planting densities 
of 5000 and 10000 trees $\mathrm{ha}^{-1}$ in a field trial in CentralItaly and measured comparably high shoot: root ratios of between 8 and 10 at the end of the second three-year rotation. The results, however, may not be directly comparable with those reported in this study. Apart from the likely growth response to harvesting following three years of growth (first rotation), the authors did not include the fine root biomass $(<2 \mathrm{~mm})$ in their calculation and, additionally, regarded the stump biomass as part of the root biomass. For lysimeter-grown basket willows (Salix viminalis L.), Rytter [44] reported shoot: root ratios, excluding leaves and cuttings, that declined from 2.5 to 1.8 in the first year and then increased to between 6.7 and 9.1 in subsequent years in clayey and sandy soils, respectively. Dušek and Květ [40] investigated different aged plantings of Salix caprea L. in a field trial in the Czech Republic. The authors reported a shoot: root ratio ranging from 3 to 4 for three-year-old plants. However, if the plantations are harvested frequently, the shoot: root ratio might be influenced.

In non- $\mathrm{N}_{2}$-fixing woody plants, biomass allocation to roots typically increases as soil $\mathrm{N}$ becomes increasingly limited [45]. Johnsen and Bongarten [46] investigated seedlings of $R$. pseudoacacia and found no impact of soil $\mathrm{N}$ availability on biomass allocation to roots. They observed no change in shoot : root ratio with increasing plant age while investigating impacts of $\mathrm{N}$-fertilization on the plants. Nevertheless, the accumulated root biomass accounts for a remarkable share of total biomass in the R. pseudoacacia plantations. Therefore, the belowground biomass may play an important role in the formation of soil humus via root and root nodule turnover and following decomposition with resultant positive influences on both soil moisture and soil fertility.

The amount of woody biomass accumulated under the imposed coppice regimes (stumps) reflects the tree management conditions within the plantation. For the seedlings and one-year-old trees, the stump (defined as the first $10 \mathrm{~cm}$ of the shoot) was within 20-25\%, compared to the shoot, a considerable compartment of the aboveground biomass. It was found that the stump compartment contributes a relative share of between $3.6 \%$ in the one-year-old plantation and $2.3 \%$ in the twelve-year-old plantation. The biomass of the stump compartment in relation to the shoot compartment decreased with plant age and thus with plant size. In the twelve-years-old plantation, the stump was seen to decrease to a share of only about $3.6 \%$ of that of the shoot. Nevertheless, the total mass of $2 \mathrm{tDM} \mathrm{ha}^{-1}$ is a considerable biomass stock as it remains after harvest at the site and together with root biomass increases the permanent baseline $\mathrm{C}$ stock in the living plant compartments.

4.3. Effects on the Carbon and Nitrogen Cycle. Gross primary production (GPP) represents the main photosynthesisderived $\mathrm{C}$ input into ecosystems but does not represent the $\mathrm{C}$ balance of a system as autotrophic and heterotrophic respiration reduces the $\mathrm{C}$ input. In a spruce forest according to Schulze [47], around $75 \%$ of the assimilatory C gain is used for respiration of the plants and roughly $25 \%$ of the C is respired by microbes within the soil. Subtracting the $\mathrm{C}$ loss due to additional disturbances (such as harvest, grazing, and fire) of the remaining biomass, only approximately $1 \%$ of the photosynthetic $\mathrm{C}$ input is stored at the biome level, or the $\mathrm{C}$ balance of the ecosystem may indeed become negative.

In the present study, the totalized above- and belowground woody biomass production, which complies with the GPP minus autotrophic respiration minus foliage biomass, in the investigated $R$. pseudoacacia plantations is $2.0 \mathrm{tDM} \mathrm{ha}^{-1} \mathrm{yr}^{-1}$ for one-year, $6.7 \mathrm{tDM} \mathrm{ha}^{-1} \mathrm{yr}^{-1}$ for twoyear, and $7.4 \mathrm{tDM} \mathrm{ha}^{-1} \mathrm{yr}^{-1}$ for the twelve-year-old stand (Figure 3). These values represent the annual C accumulation in the woody plant parts following one, two, and twelve years. For twelve years, these values correspond with an additional $\mathrm{C}$ storage of around $3.38 \mathrm{tC} \mathrm{ha}^{-1} \mathrm{yr}^{-1}$ and even if the potential yield biomass (shoot growth) is subtracted from that value an average $\mathrm{C}$ storage of $1.17 \mathrm{tCha}^{-1} \mathrm{yr}^{-1}$ in stump, fine and coarse roots can be concluded (Table 3 ).

One advantage of $R$. pseudoacacia on marginal sites is that the tree is a legume and as such has the ability to fix atmospheric $\mathrm{N}$, a nutrient that is usually limited on the Lower Lusatian reclamation sites if no additional fertilizer is applied. In the plantations under study, the trees seem to intensively fixate air $\mathrm{N}$ as the major part of the $\mathrm{N}$ is bound in the root system (the root nodules), at least up to an age of two years. Even at age twelve, the $\mathrm{N}$ stock in the root compartments is nearly as high as the $\mathrm{N}$ stock in the shoot (Table 3), although the shoot to root ratio has increased to about 2.0 in the twelfth year. Because nutrients (such as N) in woody plant parts are usually concentrated in the bark, older plants with thicker branches have lower total nutrient concentrations in lignified plant parts due to a lower bark fraction in relation to a higher fraction of nutrient-poor wood $[48,49]$. Accordingly, the shoots, stumps, and coarse roots of the older plants had wider $\mathrm{C} / \mathrm{N}$ ratios than the younger plants, whereas the $\mathrm{C} / \mathrm{N}$ ratio of the less intensively lignifying fine roots does not change substantially with increasing plant age. Furthermore, the measured $\mathrm{N}$ concentrations and $\mathrm{N}$ stocks in the shoots of $R$. pseudoacacia are higher than values reported for willow and poplar on comparable sites. Bungart and Hüttl [50] measured the nutrient contents in aboveground plant parts of different four-year-old clones of poplar, willow, and aspen on reclamation sites in the mining area of "Welzow-Süd" (average biomass productivity of the plantation was $2.3 \mathrm{tDM} \mathrm{ha}^{-1} \mathrm{yr}^{-1}$ ) and reported average contents of $4.9 \mathrm{mg} \mathrm{N} \mathrm{g}^{-1} \mathrm{DM}$ and a total $\mathrm{N}$ accumulation of $51 \mathrm{kgha}^{-1}$.

Dependent upon stand age, stand density, nutrient demand, and climate, typical annual fixation rates of $R$. pseudoacacia range between 30 and $120 \mathrm{~kg} \mathrm{Nha}^{-1}$ [41, 51,52]. Some authors report a general increase in the soil $\mathrm{N}$ under $R$. pseudoacacia cover [53], whereas the increase is not only a result of release from decaying $\mathrm{N}$-rich leaves and roots, but also from root exudates that may contain $1-2 \%$ of the recently fixed N [54]. Berthold et al. [55] also reported of higher $\mathrm{N}$ amounts under $R$. pseudoacacia forest stands in Hungary (ages ranged between 28 and 56 years) but also presented results indicating that an excess of nitrate under $R$. pseudoacacia leached together with base cations $\left(\mathrm{K}^{+}\right.$, $\left.\mathrm{Ca}^{2+}, \mathrm{Mg}^{2+}\right)$ causing soil acidification and a decrease of soil 
fertility compared to adjacent oak stands. Similar findings were reported for stands in eastern Germany [56].

The measured $\mathrm{N}$ stocks in the biomass compartments of R. pseudoacacia quantify the amount of $\mathrm{N}$ that is stored in the living woody plant compartments. In the shoot compartment alone, about $0.71 \mathrm{t} \mathrm{Nha}^{-1}$ are stored in the twelve-year-old stand compared to a total $\mathrm{N}$ storage of $1.3 \mathrm{t} \mathrm{Nha}^{-1}$ in the whole plants. This would result in an average accumulation rate of $0.11 \mathrm{t} \mathrm{N} \mathrm{ha}^{-1} \mathrm{yr}^{-1}$. Parts of this $\mathrm{N}$ are continually injected into the processes of decomposition, ammonification, nitrification, and denitrification [57] via aboveground and belowground litter fall. However, a significant $\mathrm{N}$ enrichment in the vegetation and the soil under $R$. pseudoacacia might result in high nitrification rates in the mineral soil [16]. As a result, nitrate and base cations can be leached, and, depending on the buffer capacity of the soil $\mathrm{pH}$ may decrease $[55,56]$. However, an enrichment of soil $\mathrm{N}$ in response to the presence of $R$. pseudoacacia may also have a considerable positive impact, for example, on the growth of other adjacent tree species especially on nutrient poor mining substrates [58].

The performed growth experiments in the presented study do not reveal any adverse impacts of $R$. pseudoacacia on the $\mathrm{C}$ or the $\mathrm{N}$ household. On the contrary, the selffertilization in combination with a comparatively good resistance against drought enabled $R$. pseudoacacia to be competitive compared to other fast growing tree species such as willow or poplar on the reclamation sites [9]. Furthermore, according to other studies performed on Lusatian mine sites, $R$. pseudoacacia contributes substantially to an C sequestration in the soil and a buildup of soil humus pools $[28,59]$.

\section{Conclusions}

It was found that the biomass accumulation in the woody plant parts and the annual shoot increments in the $R$. pseudoacacia plantations were higher or at least similar high as growth performances reported for willow and poplar on comparable sites. The results suggest that $R$. pseudoacacia is comparatively well adapted to the harsh growth conditions that can be found on the Lower Lusatian reclamation sites. A remaining average $\mathrm{C}$ accumulation rate in stump and roots (excluding harvest removals) of at least $1.17 \mathrm{tC} \mathrm{ha}^{-1} \mathrm{yr}^{-1}$ after twelve years of growth was estimated. At a maximum biomass accumulation rate in the woody plant parts of $7.45 \mathrm{tDM} \mathrm{ha}^{-1} \mathrm{yr}^{-1}$, a remarkable share of the woody biomass growth in the twelve-year-old plantation was allocated into the root system accounting for 34\% of the total biomass. It was found that the stump compartment contributes a relative share of between $3.6 \%$ and $2.3 \%$ of the total biomass and therefore builds together with the root biomass a notable baseline $\mathrm{C}$ stock in SRC. This mid-term C pool is SRC-specific, as it does not exist in conventional land use systems with annual energy crops.

Nitrogen stocks in the living woody biomass compartments ranged between $42.8 \mathrm{~kg} \mathrm{Nha}^{-1}$ for the one-year and $1327.2 \mathrm{~kg} \mathrm{Nha}^{-1}$ for the twelve-year-old plants (corresponding $\mathrm{N}$ stocks without shoots were $39.1 \mathrm{~kg} \mathrm{Nha}^{-1}$ and $612.5 \mathrm{~kg} \mathrm{Nha}^{-1}$ ), confirming that the living biomass compartments in the $R$. pseudoacacia plantations may represent a considerable source of $\mathrm{N}$ input into the $\mathrm{N}$-poor reclamation systems via the processes of decomposition.

In regards to the produced shoot biomass as a possible replacement for fossil energy resources and the accumulated stump and root biomass as advantageous for $\mathrm{C}$ sequestration, soil humus status, and general site fertility, the results suggest that $R$. pseudoacacia would be a good candidate for biomass production in SRC systems on reclamation sites and other marginal lands. Assuming a life time of 20-30 years for a SRC with a following conversion of the plantation back into agricultural land, as was demonstrated for a study site in Lusatia [60], the $C$ sequestration capacity of a landscape could be enhanced by establishing a rotation system with alternating cultivation of conventional crops and SRC. If the areas for SRC are shifted, the permanent existence of a root and a stump pool for C storage would be ensured. Furthermore, conventional crops would benefit from higher soil humus and soil $\mathrm{N}$ contents if they were cultivated on former SRC areas after removal of the plantation. However, knowledge of the $\mathrm{C}$ and $\mathrm{N}$ household in $R$. pseudoacacia plantations on reclamation sites and possible implications for soil quality are still somewhat incomplete. Further investigations (e.g., additional sampling of plants at complementary ages with a focus on element flows and turnover processes) would help to receive a more solid data base and to obtain a more detailed picture of the $\mathrm{C}$ and $\mathrm{N}$ translocation processes within the plantations.

\section{Acknowledgments}

This study was supported by the German Federal Ministry of Education and Research as project DENDROM (no. 0330580 A-F, H) and by the Vattenfall Europe Mining AG as project ANFOREK.

\section{References}

[1] W. A. Geyer, "Biomass yield potential of short-rotation hardwoods in the great plains," Biomass, vol. 20, no. 3-4, pp. 167175, 1989.

[2] T. Strong, "Rotation length and repeated harvesting influence on Populus coppice production," Tech. Rep. NC 350, USDA Forest Service, North Central Forest Experiment Station, 1989.

[3] C. Hofmann-Schielle, A. Jug, F. Makeschin, and K. E. Rehfuess, "Short-rotation plantations of balsam poplars, aspen and willows on former arable land in the Federal Republic of Germany. I. Site-growth relationships," Forest Ecology and Management, vol. 121, no. 1-2, pp. 41-55, 1999.

[4] V. Scholz and R. Ellerbrock, "The growth productivity, and environmental impact of the cultivation of energy crops on sandy soil in Germany," Biomass and Bioenergy, vol. 23, no. 2, pp. 81-92, 2002.

[5] C. P. Mitchell, E. A. Stevens, and M. P. Watters, "Shortrotation forestry-operations, productivity and costs based on experience gained in the UK," Forest Ecology and Management, vol. 121, no. 1-2, pp. 123-136, 1999.

[6] A. Lindroth and A. Båth, "Assessment of regional willow coppice yield in Sweden on basis of water availability," Forest Ecology and Management, vol. 121, no. 1-2, pp. 57-65, 1999. 
[7] U. Penth, G. Milojcic, F. Hausmann, K. van de Loo, M. Chromik, and U. Maaßen, "Der Kohlenbergbau in der Energiewirtschaft der Bundesrepublik Deutschland im Jahre 2009," Statistik der Kohlenwirtschaft e.V., 2010.

[8] R. Bungart and R. F. Hüttl, "Growth dynamics and biomass accumulation of 8-year-old hybrid poplar clones in a shortrotation plantation on a clayey-sandy mining substrate with respect to plant nutrition and water budget," European Journal of Forest Research, vol. 123, no. 2, pp. 105-115, 2004.

[9] H. Gruenewald, B. K. V. Brandt, B. U. Schneider, O. Bens, G. Kendzia, and R. F. Hüttl, "Agroforestry systems for the production of woody biomass for energy transformation purposes," Ecological Engineering, vol. 29, no. 4, pp. 319-328, 2007.

[10] E. F. Gilman and D. G. Watson, "Robinia pseudoacacia-Black locust," United States Department of Agriculture (USDA) Forest Service, Fact Sheet ST-570, 1994.

[11] C. Waitkus and H. G. Richter, "Die Robinie und ihr Holz," Bundesforschungsanstalt für Forst- und Holzwirtschaft (BFH), 2001.

[12] J. J. Balatinecz and D. E. Kretschmann, "Properties and utilization of poplar wood," in Poplar Culture in North America, D. I. Dickmann, J. G. Isebrands, J. E. Eckenwalder, and J. Richardson, Eds., pp. 277-291, NRC Research Press, Ottawa, Canada, 2001.

[13] B. Klasnja, S. Kopitovic, and S. Orlovic, "Wood and bark of some poplar and willow clones as fuelwood," Biomass and Bioenergy, vol. 23, no. 6, pp. 427-432, 2002.

[14] L. Qiu, X. Zhang, J. Cheng, and X. Yin, "Effects of black locust (Robinia pseudoacacia) on soil properties in the loessial gully region of the Loess Plateau, China," Plant and Soil, vol. 332, no. 1-2, pp. 207-217, 2010.

[15] D. A. N. Ussiri, R. Lal, and P. A. Jacinthe, "Soil properties and carbon sequestration of afforested pastures in reclaimed minesoils of Ohio," Soil Science Society of America Journal, vol. 70, no. 5, pp. 1797-1806, 2006.

[16] F. Montagnini, B. Haines, L. Boring, and W. Swank, "Nitrification potentials in early successional black locust and in mixed hardwood forest stands in the southern Appalachians, USA," Biogeochemistry, vol. 2, no. 2, pp. 197-210, 1986.

[17] D. Landgraf, S. Wedig, and S. Klose, "Medium- And shortterm available organic matter, microbial biomass, and enzyme activities in soils under Pinus sylvestris L. and Robinia pseudoacacia L. in a sandy soil in NE Saxony, Germany," Journal of Plant Nutrition and Soil Science, vol. 168, no. 2, pp. 193-201, 2005.

[18] K. S. Olesniewicz and R. B. Thomas, "Effects of mycorrhizal colonization on biomass production and nitrogen fixation of black locust (Robinia pseudoacacia) seedlings grown under elevated atmospheric carbon dioxide," New Phytologist, vol. 142, no. 1, pp. 133-140, 1999.

[19] R. Tateno, N. Tokuchi, N. Yamanaka et al., "Comparison of litterfall production and leaf litter decomposition between an exotic black locust plantation and an indigenous oak forest near Yan'an on the Loess Plateau, China," Forest Ecology and Management, vol. 241, no. 1-3, pp. 84-90, 2007.

[20] Y. C. Lee, J. M. Nam, and J. G. Kim, “The influence of black locust (Robinia pseudoacacia) flower and leaf fall on soil phosphate," Plant and Soil, vol. 341, no. 1-2, pp. 269-277, 2011.

[21] T. Yüksek and F. Yüksek, "The effects of restoration on soil properties in degraded land in the semi-arid region of Turkey," Catena, vol. 84, no. 1-2, pp. 47-53, 2011.

[22] O. Rahmonov, "The chemical composition of plant litter of black locust (Robinia pseudoacacia L.) and its ecological role in sandy ecosystems," Acta Ecologica Sinica, vol. 29, no. 4, pp. 237-243, 2009.

[23] B. C. Bongarten, D. A. Huber, and D. K. Apsley, "Environmental and genetic influences on short-rotation biomass production of black locust (Robinia pseudoacacia L.) in the Georgia Piedmont," Forest Ecology and Management, vol. 55, no. 1-4, pp. 315-331, 1992.

[24] R. M. Burns and B. H. Honkala, Silvics of North America: 2. Hardwoods, vol. 654 of Agriculture Handbook, U.S. Department of Agriculture, Forest Service, Washington, DC, USA, 1990.

[25] J. D. Zeleznik and J. G. Skousen, "Survival of three tree species on old reclaimed surface mines in Ohio," Journal of Environmental Quality, vol. 25, no. 6, pp. 1429-1435, 1996.

[26] K. Rédei, I. Csiha, and Z. Keserü, "Black locust (Robinia pseudoacacia L.) short-rotation crops under marginal site conditions," Acta Silvatica et Lignaria Hungarica, vol. 7, pp. 125132, 2011.

[27] A. Quinkenstein, H. Jochheim, B. U. Schneider, and R. F. Hüttl, "Modellierung des Kohlenstoffhaushalts von PappelKurzumtriebsplantagen in Brandenburg," in Anbau und Nutzung von Bäumen auf landwirtschaftlichen Flächen, T. Reeg, A. Bemmann, W. Konold, D. Murach, and H. Spiecker, Eds., pp. 193-203, Wiley-VCH, Weinheim, Germany, 2009.

[28] A. Quinkenstein, C. Böhm, E. Matos, D. Freese, and R. F. Hüttl, "Assessing the carbon sequestration in short rotation coppice systems of Robinia pseudoacacia on marginal sites in NE-Germany," in Carbon Sequestration Potential of Agroforestry Systems, B. M. Kumar and P. K. R. Nair, Eds., vol. 8, Advances in Agroforestry, Springer, 2011.

[29] J. Katzur and M. Haubold-Rosar, "Amelioration and reforestation of sulfurous mine soils in Lusatia (Eastern Germany)," Water, Air, and Soil Pollution, vol. 91, no. 1-2, pp. 17-32, 1996.

[30] L. Kutschera and E. Lichtenegger, Wurzelatlas Mitteleuropäischer Waldbäume und Sträucher, Leopold Stocker, Graz, Austria, 2002.

[31] A. G. Bengough, A. Castrignano, L. Pages, and M. van Noordwijk, "Sampling strategies, scaling, and statistics," in Root Methods: A Handbook, A. L. Smit, A. G. Bengough, C. Engels, M. van Noordwijk, S. van de Pellerin, and S. C. Geijn, Eds., pp. 147-173, Springer, Berlin, Germany, 2000.

[32] R. Ihaka and R. Gentleman, "R: a language for data analysis and graphics," Journal of Computational and Graphical Statistics, vol. 5, no. 3, pp. 299-314, 1996.

[33] H. B. Mann and D. R. Whitney, "On a test of whether one of two random variables is stochastically larger than the other," Annals of Mathematical Statistics, vol. 18, no. 1, pp. 50-60, 1947.

[34] H. Grünewald, C. Böhm, A. Quinkenstein, P. Grundmann, J. Eberts, and G. von Wühlisch, "Robinia pseudoacacia L.: a lesser known tree species for biomass production," Bioenergy Research, vol. 2, no. 3, pp. 123-133, 2009.

[35] C. Böhm, A. Quinkenstein, D. Freese, and R. F. Hüttl, "Wachstumsverlauf von vierjährigen Robinien," AFZ-DerWald, vol. 10, pp. 532-533, 2009.

[36] K. Peters, G. Bilke, and B. Strohbach, "Ertragsleistung sechsjähriger Robinien (Robinia pseudoacacia) auf vier ehemaligen Ackerstandorten unterschiedlicher Bodengüte in Brandenburg," Archiv für Forstwesen und Landschaftsökologie, vol. 41, pp. 26-28, 2007.

[37] D. I. Dickmann, K. Steinbeck, and T. Skinner, "Leaf area and biomass in mixed and pure plantations of sycamore and black locust in the Georgia Piedmont," Forest Science, vol. 31, no. 2, pp. 509-517, 1985. 
[38] D. W. Cole and M. Rapp, "Elemental cycling in forest ecosystems," in Dynamic Properties of Forest Ecosystems, D. Reichle, Ed., vol. 23, pp. 341-409, International Biological Programme Synthesis, Cambridge University Press, Malta, 1981.

[39] H.-S. Helmisaari, K. Makkonen, S. Kellomäki, E. Valtonen, and E. Mälkönen, "Below- and above-ground biomass, production and nitrogen use in Scots pine stands in eastern Finland," Forest Ecology and Management, vol. 165, no. 1-3, pp. 317-326, 2002.

[40] J. Dušek and J. Květ, "Seasonal dynamics of dry weight, growth rate and root/shoot ratio in different aged seedlings of Salix caprea," Biologia, vol. 61, no. 4, pp. 441-447, 2006.

[41] L. R. Boring and W. T. Swank, "The role of black locust (Robinia pseudoacacia) in forest succession," Journal of Ecology, vol. 72, no. 3, pp. 749-766, 1984.

[42] M. D. Coleman, A. L. Friend, and C. C. Kern, "Carbon allocation and nitrogen acquisition in a developing Populus deltoides plantation," Tree Physiology, vol. 24, no. 12, pp. 13471357, 2004.

[43] M. Liberloo, C. Calfapietra, M. Lukac et al., "Woody biomass production during the second rotation of a bio-energy Populus plantation increases in a future high $\mathrm{CO}_{2}$ world," Global Change Biology, vol. 12, no. 6, pp. 1094-1106, 2006.

[44] R.-M. Rytter, "Biomass production and allocation, including fine-root turnover, and annual $\mathrm{N}$ uptake in lysimeter-grown basket willows," Forest Ecology and Management, vol. 140, no. 2-3, pp. 177-192, 2001.

[45] K. J. Nadelhoffer, "The potential effects of nitrogen deposition on fine-root production in forest ecosystems," New Phytologist, vol. 147, no. 1, pp. 131-139, 2000.

[46] K. H. Johnsen and B. C. Bongarten, "Relationships between nitrogen fixation and growth in Robinia pseudoacacia seedlings: a functional growth-analysis approach using ${ }^{15} \mathrm{~N}, "$ Physiologia Plantarum, vol. 85, no. 1, pp. 77-84, 1992.

[47] E.-D. Schulze, "Biological control of the terrestrial carbon sink," Biogeosciences, vol. 3, no. 2, pp. 147-166, 2006.

[48] H. G. Adegbidi, T. A. Volk, E. H. White, L. P. Abrahamson, R. D. Briggs, and D. H. Bickelhaupt, "Biomass and nutrient removal by willow clones in experimental bioenergy plantations in New York state," Biomass and Bioenergy, vol. 20, no. 6, pp. 399-411, 2001.

[49] P. J. Tharakan, T. A. Volk, L. P. Abrahamson, and E. H. White, "Energy feedstock characteristics of willow and hybrid poplar clones at harvest age," Biomass and Bioenergy, vol. 25, no. 6, pp. 571-580, 2003.

[50] R. Bungart and R. F. Hüttl, "Production of biomass for energy in post-mining landscapes and nutrient dynamics," Biomass and Bioenergy, vol. 20, no. 3, pp. 181-187, 2001.

[51] L. R. Boring and W. T. Swank, "Symbiotic nitrogen fixation in regenerating black locust (Robinia pseudoacacia L.) stands," Forest Science, vol. 30, no. 2, pp. 528-537, 1984.

[52] S. K. A. Danso, F. Zapata, and K. O. Awonaike, "Measurement of biological $\mathrm{N}_{2}$ fixation in field-grown Robinia pseudoacacia L," Soil Biology and Biochemistry, vol. 27, no. 4-5, pp. 415-419, 1995.

[53] J. P. Vimmerstedt, M. C. House, M. M. Larson, J. D. Kasile, and B. L. Bishop, "Nitrogen and Carbon accretion on Ohio coal minesoils: Influence of soil-forming factors," Landscape and Urban Planning, vol. 17, no. 2, pp. 99-111, 1989.

[54] S. M. Uselman, R. G. Qualls, and R. B. Thomas, "A test of a potential short cut in the nitrogen cycle: the role of exudation of symbiotically fixed nitrogen from the roots of a $\mathrm{N}$-fixing tree and the effects of increased atmospheric $\mathrm{CO}_{2}$ and temperature," Plant and Soil, vol. 210, no. 1, pp. 21-32, 1999.
[55] D. Berthold, T. Vor, and F. Beese, "Soil degradation by Black locust (Robinia pseudoacacia L.)," in Biological Invasionsfrom Ecology to Control, W. Nentwig, S. Bacher, M. Cock, H. J. Dietz, A. Gigon, and R. Wittenberg, Eds., pp. 67-78, Neobiota 6, Berlin, Germany, 2005.

[56] S. Goldacker, D. Berthold, F. Beese et al., "Bodenversauerung unter Robinie-Potenzielle Ursache von Wachstumsminderungen?" AFZ Der Wald, vol. 19, pp. 1003-1006, 2002.

[57] B. H. Svensson and R. Söderlund, Eds., "Nitrogen, phosphorus and sulphur-global cycles," SCOPE Report 7, p. 192, Scientific Committee on Problems of the Environment (SCOPE), Stockholm, Sweden, Ecological Bulletins no. 22, 1975.

[58] P. Ntayombya and A. M. Gordon, "Effects of black locust on productivity and nitrogen nutrition of intercropped barley," Agroforestry Systems, vol. 29, no. 3, pp. 239-254, 1995.

[59] E. S. Matos, D. Freese, C. Böhm, A. Quinkenstein, and R. F. Hüttl, "Organic matter dynamics in reclaimed lignite mine soils under Robinia pseudoacacia L. plantations of different ages in Germany," Communications in Soil Science and Plant Analysis, vol. 43, no. 5, pp. 745-755, 2012.

[60] A. Quinkenstein, C. Böhm, and D. Freese, "Zurück auf Los," DLZ Agrar Magazin, vol. 7, pp. 50-51, 2010. 

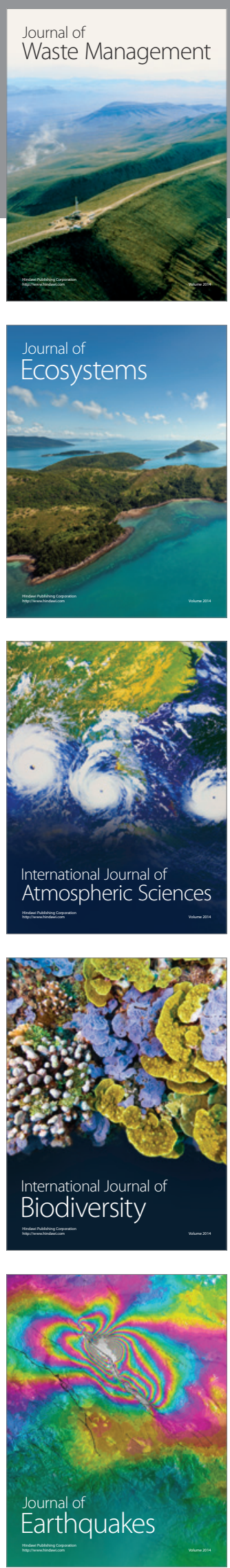
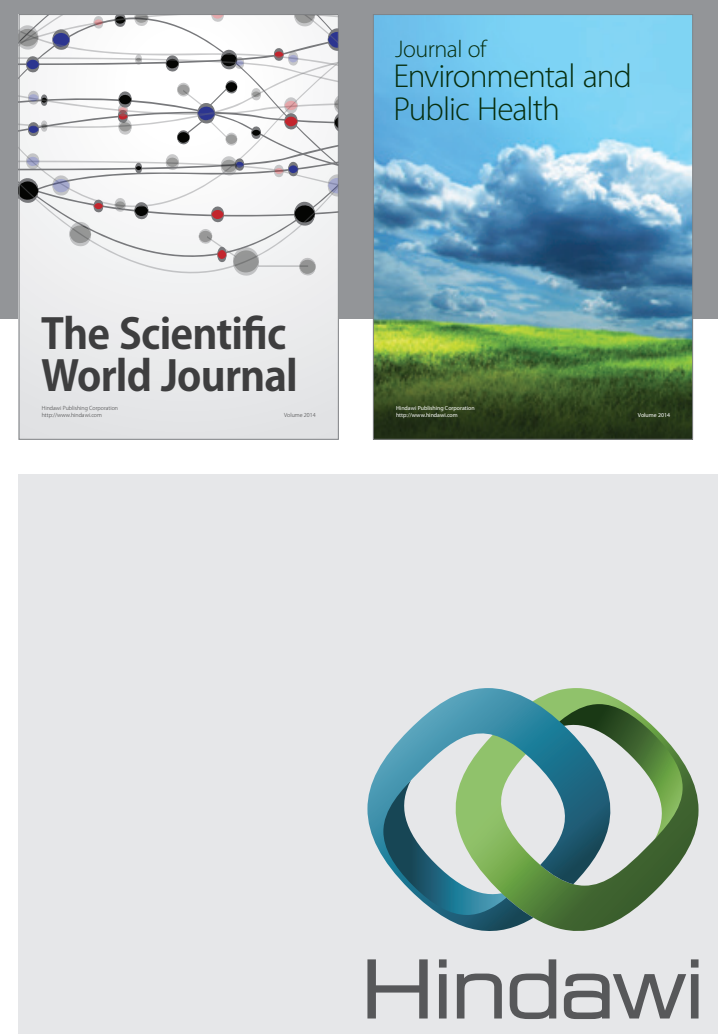

Submit your manuscripts at

http://www.hindawi.com
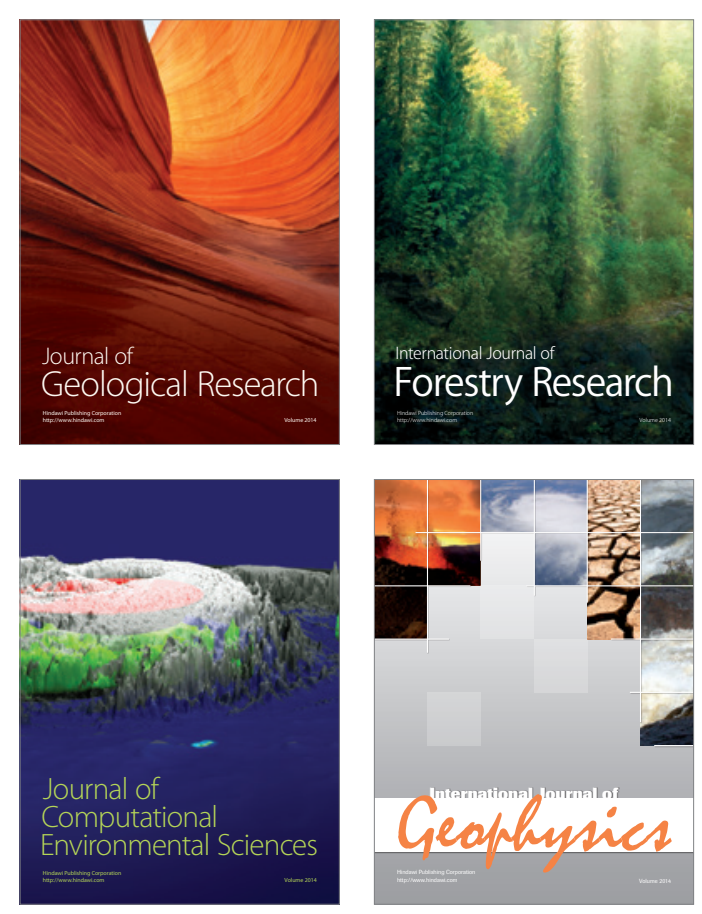
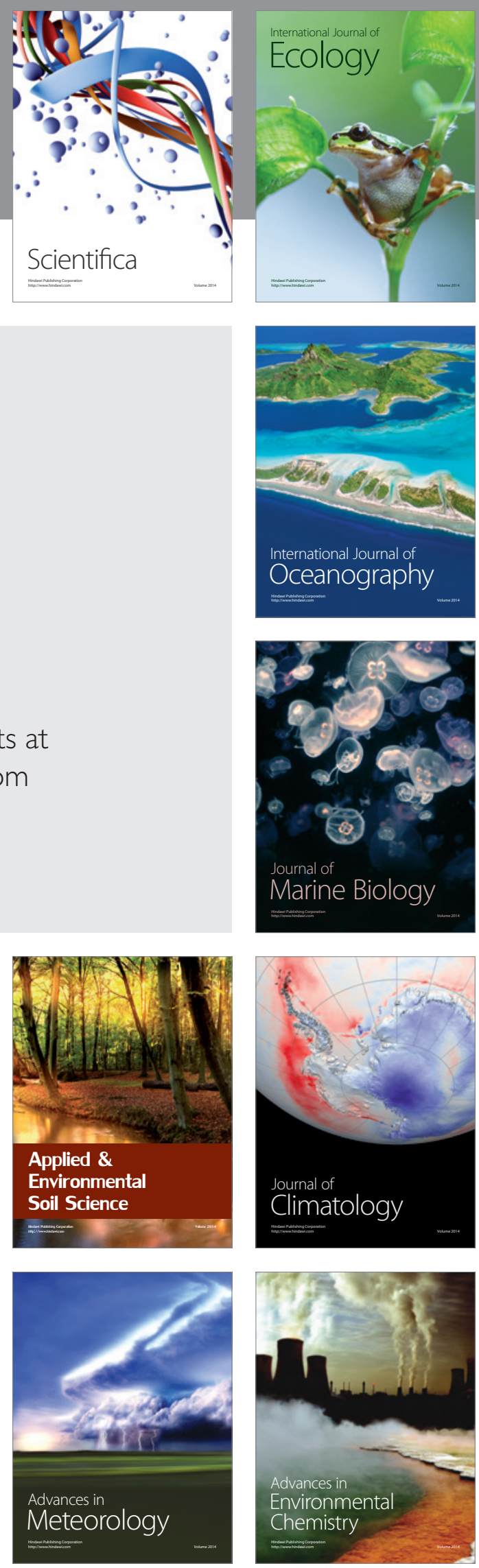